\title{
'There's No Birthright' and Other Tips for Raising Entrepreneurial Leaders
}

\author{
Kimberly Eddleston (Northeastern University)
}

\section{KEYWORDS: Construction, Entrepreneurship,} Management, Leadership, Family Business.

Joe Brito, the third-generation head of C.B. Utility Co. (http://www.cb-utility.com/) in Bristol, Rhode Island, started his career in the family business as a laborer. He firmly believes that anybody entering their family business start at the bottom: "Come in through the downstairs door...not the upstairs," he says. In this interview with Northeastern University Professor Kim Eddleston, an editor at EIX.org (https://familybusiness.org/) and FamilyBusiness.org (https://familybusiness.org/), Brito shares the secrets of success for his family business, which has survived an astounding four generations. Other bits of advice? There's no birthright for relatives. Make them apply for jobs in the family firm. Kiss them on the cheek AND kick them in the butt when necessary. Brito's words of wisdom will hit home for anyone trying to make both the family and the business successful.

\section{Learn More:}

What It Takes to Build a Four-Generation Business (https://familybusiness.org/content/What-it-takes-to-

build-a-four-generation) 